\title{
Improving The Understanding of Way Huwi Community Towards Water Quality for Drinking Purpose Using Door to Door Method
}

\author{
Luhut Pardamean Siringoringo, Sandi Maulana \\ Institut Teknologi Sumatera \\ E-mail: luhut.pardamean@gl.itera.ac.id
}

\begin{tabular}{|c|c|}
\hline Article History: & act: The atmosphere of the COVID 19 pandemic \\
\hline Received: July $14^{\text {th }} 2020$ & changed the pattern of community service. In this case \\
\hline Revised: Jan 14th 2021 & the Door to Door method is the best choice. The area of \\
\hline Accepted: May 30 2021 & $\begin{array}{l}\text { training is Way Huwi Village because of high economic } \\
\text { growth. The principle of this method is that the speakers } \\
\text { come to people's houses with the aim of disseminating } \\
\text { the results of their research. The case study conducted in }\end{array}$ \\
\hline $\begin{array}{l}\text { Keywords: door to door, Way } \\
\text { Huwi, drinking, COVID } 19\end{array}$ & $\begin{array}{l}\text { order to identify groundwater well specifically for } \\
\text { drinking purposes. This method will be better applied if } \\
\text { previous research has been done. The results of the } \\
\text { training show that the community can only distinguish } \\
\text { water quality based on physicality alone. We need train } \\
\text { the community so they can understand the principles of } \\
\text { water for drinking purpose. The community response } \\
\text { was very good with the many questions asked. This } \\
\text { might be different if done in a room with many } \\
\text { participants. }\end{array}$ \\
\hline
\end{tabular}

\section{Introduction}

Indonesia has been officially infected with COVID 19 since last March 2020. This has a great influence on the activities of the Tri Dharma of Higher Education, one of which is community service. Before COVID 19 emerged, community devotion activities always involved many people such as training at the Village Hall, in schools, and in the large field. We need to share our's experience on 2018 when doing community devotion with the door to door method because this method is a method that can be done during the pandemic as it is now considering not gathering a lot of people and keeping distance can still be done.

Way Huwi Village is a village that is very close to ITERA Campus, Bandar Lampung City and Kota Baru Toll Gate (Figure 1). Strategically, the location is very good. In addition, The water resources so abundant because of part of Metro-Kotabumi 
Groundwater Basin ${ }^{1}$. The village has been shining since ITERA was established in 2014. The economy will continue to grow along with the growing number of students ${ }^{2}$. Furthermore, as assumption, there will be an increase in the number of well 10\%/year ${ }^{3}$. This must be balanced with an understanding of the quality of groundwater that is suitable for drinking. Unfortunately, this understanding will get harder because this is doesn't supported by good level of education. The majority of South Lampung society which is 15 years of age or older has educational background only from elementary until higher school ${ }^{4}$ (Table 1). They might didn't get knowledge about water analysis when they school. Based on Survey on 2018, more than nine house using dig well for their household needs. The physical quality was good like smell, taste, colour, and cloudy. But the problem was the community can not observe in micro scale. We worry the community used the water for drinking purpose. The water might be didn't good for drinking. The purpose of this devotion is to train society towards the water quality for drinking purpose in physical or chemical/biology/micro scale thus they can distinguish water that proper to drink.

The material provided at the time of community devotion is material on how to analyze groundwater so that it can distinguish groundwater as what is suitable for drinking. The chosen community is the community whose well have been researched on groundwater quality by the author/us. We need to discuss this topic considering that from time to time the level of groundwater pollution is increasingly alarming. Good knowledge of nature in this case is groundwater will bring prosperity to the community. Vice versa, lack of community knowledge about groundwater can adversely affect the community itself ${ }^{5}$. A good relationship with nature and with fellow humans will create stability and vice versa will create problems ${ }^{6}$. The expected outcome of this training is the community can distinguish potable groundwater based on physical and laboratory aspects. Able to read the content of water and critizm to his/her environment. In addition, the community can be a mentor to their neighbors and family. By doing this training it is hoped that the community will not arbitrarily take groundwater for

${ }^{1}$ Susilo Bambang Yudhoyono, Daftar Cekungan Airtanah Di Indonesia, 2011.

${ }^{2}$ Luhut Pardamean Siringoringo, Reza Rizki, and Janner Nababan, "Engineering, Environment, and Technology Hydrogeochemical and Groundwater Assessment for Drinking Purpose at ITERA Campus Area and Its Surroundings," Journal of Geoscience, Engineering, Environment, and Technology 04, no. 01 (2019): 40-48.

3 Dheni Saputra JP, Ofik Taufik Purwadi, and Sumiharni, "Studi Air Tanah Berbasis Geographics Information System (GIS) Di Kota Bandar Lampung,” Rekayasa Sipil dan Desain 4, no. 3 (2016): 469-480.

4 Badan Pusat Statistik Kabupaten Lampung Selatan, STATISTIK KESEJAHTERAAN RAKYAT KABUPATEN LAMPUNG SELATAN 2020, 2020.

5 Dian Agustina, "Pendampingan Mitigasi Bencana Gempa Bumi Dan Tsunami Berbasis Pengetahuan Lokal Pada Masyarakat Rentan Bencana Di Kabupaten Mukomuko Bengkulu," Engagement: Jurnal Pengabdian Kepada Masyarakat 1, no. 3 (2020): 87-99.

6 Resa Dandirwalu et al., "Pendampingan Perilaku Hidup Bersih Dan Sehat Berbasis Gereja Di Sekolah Minggu Jemaat Gereja Protestan Maluku (GPM) Tihulale Kabupaten Seram Bagian Barat," Engagement: Jurnal Pengabdian Kepada Masyarakat 4, no. 1 (2020): 225-236. 
consumption.

Table 1. The Percentages of South Lampung society which is 15 years of age or older, according the characteristics and highest certificate that have been owned

\begin{tabular}{lccccc}
\hline Characteristics & $\begin{array}{c}\text { No } \\
\text { Elementary } \\
\text { School } \\
\text { Certificate }\end{array}$ & $\begin{array}{c}\text { Elementary } \\
\text { School or } \\
\text { equal }\end{array}$ & $\begin{array}{c}\text { Junior High } \\
\text { School or equal }\end{array}$ & $\begin{array}{c}\text { Senior High } \\
\text { School and } \\
\text { upper }\end{array}$ & Total \\
\hline Gender & & & & & \\
\hline Man & 14,67 & 25,28 & 26,06 & 34,00 & 100 \\
\hline Woman & 21,17 & 26,58 & 25,16 & 27,08 & 100 \\
\hline Spending Group & & & & & \\
\hline $40 \%$ bottom & 24,60 & 27,56 & 27,14 & 20,70 & 100 \\
\hline $40 \%$ midde & 15,58 & 28,84 & 27,51 & 28,07 & 100 \\
\hline $20 \%$ upper & 10,62 & 17,68 & 19,51 & 52,19 & 100 \\
\hline South & 17,84 & 25,91 & 25,62 & 30,63 & 100 \\
\hline Lampung & & & & & \\
\hline
\end{tabular}

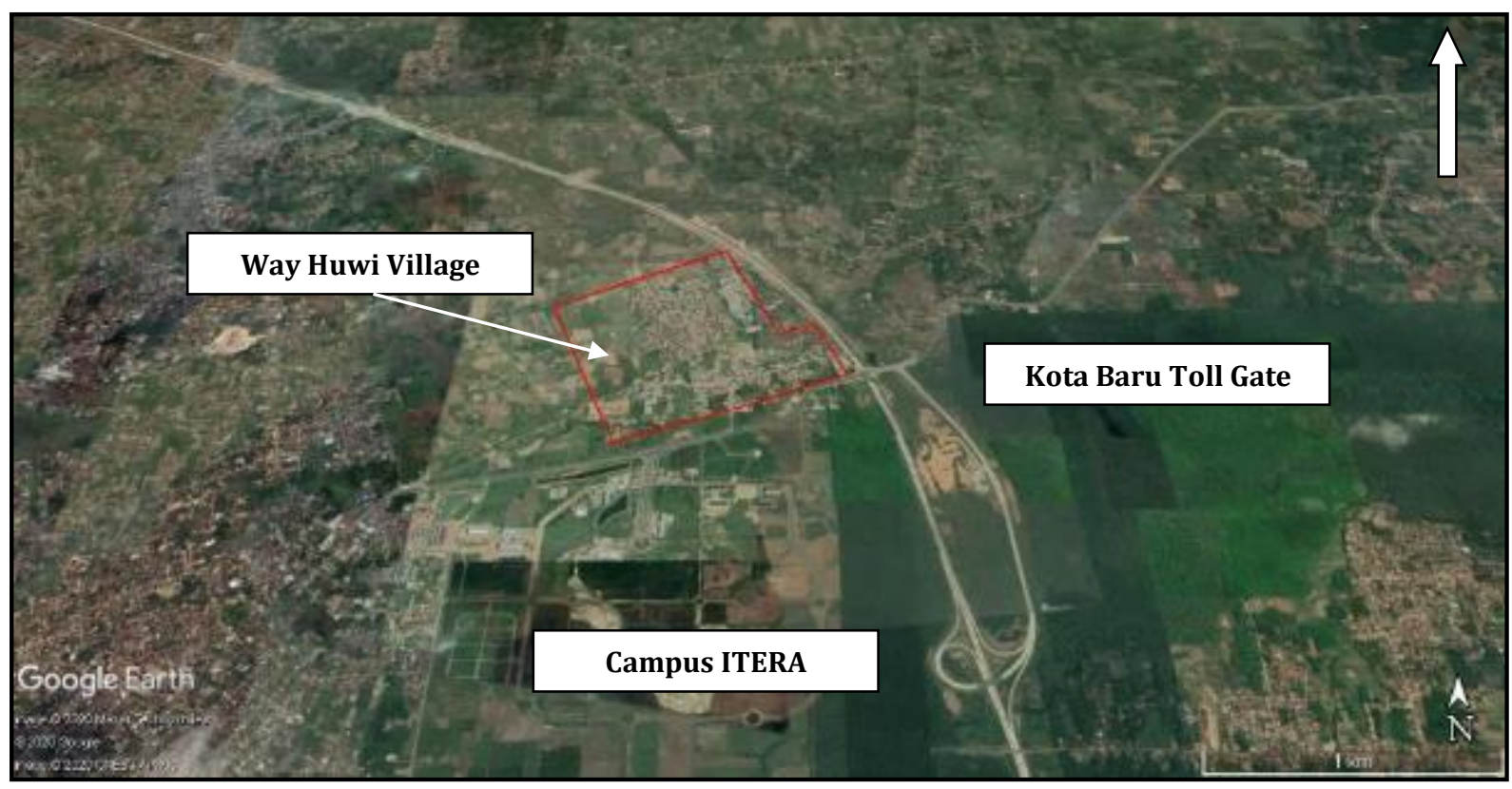

Figure 1. The general map of community devotion location 
The reason why we choose Way Huwi Village is the village is very strategist for community development in the future. The village that is very close to ITERA Campus, Bandar Lampung City and Kota Baru Toll Gate (Figure 1). The water resources so abundant because of part of Metro-Kotabumi Groundwater Basin. The village has been shining since ITERA was established in 2014. The economy will continue to grow along with the growing number of students. Furthermore, as assumption, there will be an increase in the number of well 10\%/year. This must be balanced with an understanding of the quality of groundwater that is suitable for drinking. Unfortunately, this understanding will get harder because this is doesn't supported by good level of education.

The expected outcome of this training is the community can distinguish potable groundwater based on physical and laboratory aspects. Able to read the content of water and critizm to his/her environment. In addition, the community can be a mentor to their neighbors and family. By doing this training it is hoped that the community will not arbitrarily take groundwater for consumption.

\section{Method}

The training activities were carried out in Way Huwi Village on June 29, 2018. The detail of location is about 250 meter space one to another house. The communities that were the object of this training were the communities that had been visited by us for groundwater research activities (Figure 2). The involvement of communities did not hard to get because we had permission letter and ever met in another project. But, we had asked before did they want joint to our devotion. We explained what our purpose. The majority of community worked as trader, labor, housewife, and farmer. In addition, they had low-middle educational background, such as elementary until senior high school. In order to understand and achieve the purpose of this devotion, then we did the material delivery slowly and language that is easy to understand. material delivery accompanied by the application of water quality recognition. So, we gave examples of water that is not worth drinking and worth drinking. The submission of material by oral and paper that has been laminated. The paper is a guideline for community training that contains a summary of groundwater quality research results. 


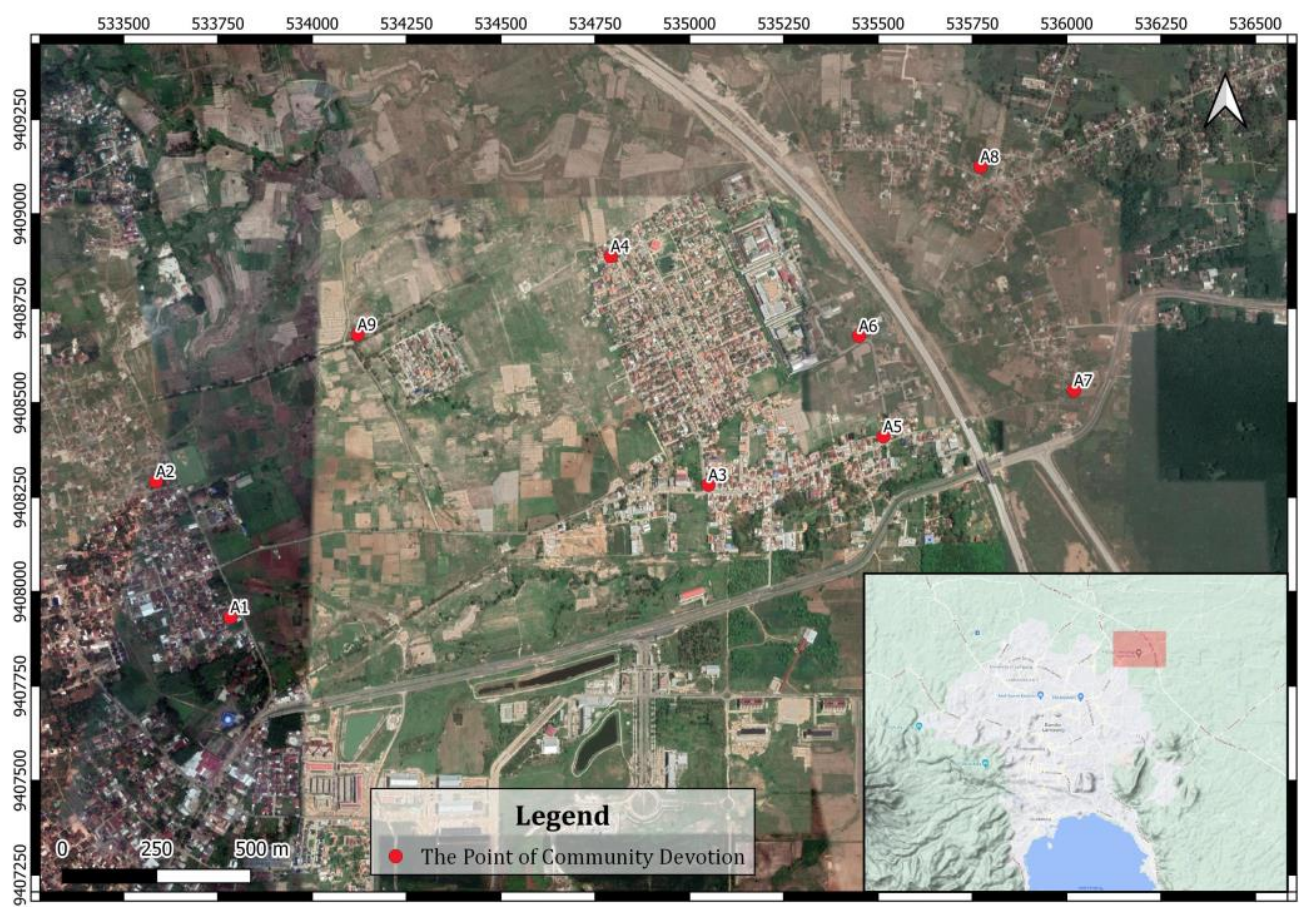

Figure 2. The specific position of community devotion. Insert map shows the location of devotion near BandarLampung City

This community training used the door to door or lecturing method. In this method, the presenter went to the houses of the community using a motorcycle and then presented the results of the research to the community. Before did the devotion, presenter took the permission to Head of Village. We used this method with various considerations. The considerations are cheap, effective, and minimal permission. In addition to these considerations, there are other things that are lacking in this method, namely the level of public education, the continuing expansion of knowledge, and the level of community acceptance. All steps of this devotion can be seen in Figure 3.

In the preparation of community training and implementation, the funds needed are not too large. We only spent approximately one hundred thirty-five thousand rupiahs to visit around nine community houses. Details of costs can be seen in 
Table 2 . 
Table 2. Costs incurred during preparation and implementation of training

\begin{tabular}{clc}
\hline No. & \multicolumn{1}{c}{ No. Goods / Expenses } & (Rp) \\
\hline 1. & Print 10 sheets of A4 color paper & 10.000 \\
\hline 2. & Laminating paper A4 10 sheets & 25000 \\
\hline 3. & Premium fuel & 20.000 \\
\hline 4. & Lunch & 30.000 \\
\hline 5. & Honor 1 assistant & 50.000 \\
\hline \multicolumn{2}{c}{ Total } \\
\hline
\end{tabular}

From the aspect of effectiveness, through this method all scientific aspects can be given comprehensively, and comfortably without any outside interference. This is very different if the training is done in a place or room. Submission of material is constrained because of the large number of people gathered. In addition, community activities that are not training participants can disrupt the smoothness delivery of material.

The permission aspect is very minimal in this method. The we only took care of the permit at the Village Office with a waiting period of only a few minutes. This is very different when using a room because you have to make a permit to use the room first.

The mechanism of providing materials like regular lectures on campus, such as talk, ask-answer, and discussion. The differences are the media and the language of delivery are simpler. Hopefully the public will be more accepting of the knowledge delivered. The use of scientific terms was avoided in this activity. Then we replace it with simple language but it does not detract the meaning.

From all the positive aspects above, this method also has negative aspects. The first negative is the relatively low level of community education (majority is elementary till high school) is very influential on the level of community understanding of the material or science provided. Therefore, the presenter must adapt with use nonscientific language so that people can understand. The continuation of scientific expansion is also hampered because the community may not be able to provide material to family members or neighbors. Then the aspect of community acceptance of people outside their environment can be a barrier because not all communities are open to strangers considering crime is increasingly rampant. This could be a loss for the community. 


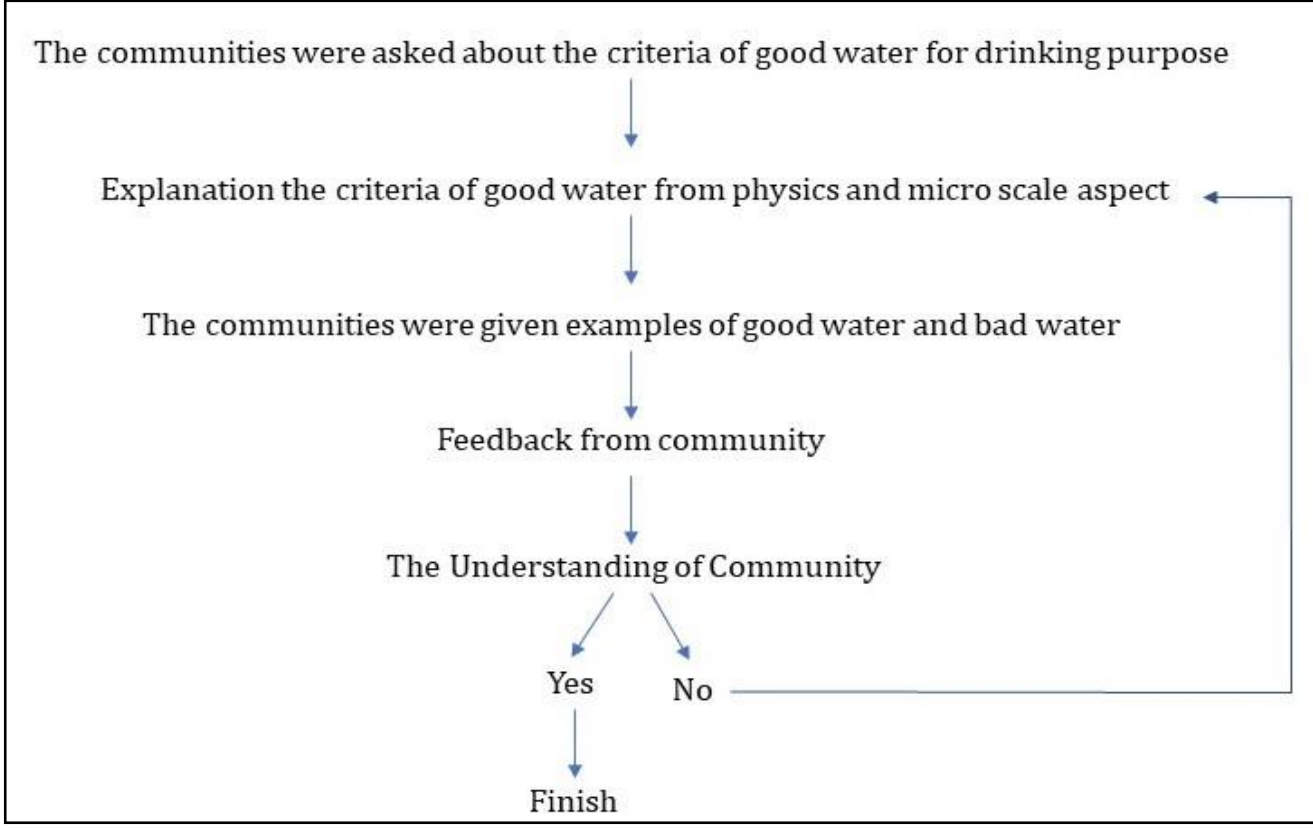

Figure 3. The flow chart of devotion steps

\section{Result}

Based on the community training activities on 29 June 2018 for nine training participants (Figure 2), the following can be described. Basically, the community could be distinguished the characteristics of groundwater such as what can be cooked for drinking water. However, it can only be seen from the physical aspects such as the color of water, odorless, uncloudy, and tasteless. We asked the community about the criteria of good water quality, they could answer but only in physical aspect. The preliminary result show that they could not identify at very small sizes such as E. Coli microbial content and the content of chemical elements/ compounds such as $\mathrm{Pb}, \mathrm{Cl}, \mathrm{SO}_{4}$ etc based on information from lab result. So, we continued to give explanation to the community about the criteria of good water and poor water from physical and moleculer aspect. We also gave the right examples of poor water and good water. We also gave explanation that If microbes are taken alive and the elements/ compounds exceed a predetermined threshold, they will be fatal, especially if drunk in the long time period (Figure 5). As example, the standard content for $\mathrm{Cl}$ is not more than $250 \mathrm{mg} / \mathrm{l}$. If we drink water which has high $\mathrm{Cl}$ content (> $250 \mathrm{mg} / \mathrm{L}$ ), it will be deposited in our body and disease in long time period. The $\mathrm{Cl}$ in water especially came from the contact of water with volcanic rocks like tuff or breccia. Finally, the communities has been understand and able to identify or read the chemical and biology content.

Prior to the training activities, research had been carried out by taking groundwater samples in community dig wells. The groundwater samples were sent to 
the Water Quality Laboratory of the Faculty of Civil and Environmental Engineering (ITB) using the standard methods for The Examination of Water and Wastewater 22nd Edition 2012 (APHA). Based on lab results it can be seen that groundwater in the study area was not suitable for consumption 7 (Figure 6). As an example, A8 (water sample) has Fe $0,581 \mathrm{mg} / \mathrm{L}$. The standard not more than $0,3 \mathrm{mg} / \mathrm{L}$. then, could be concluded that the Fe content in A8 is very high and not for drinking. The high Fe usually came from the long contact between water and high Fe rocks.

Referring to the lab results described in the previous paragraph, the groundwater identification training gave more understanding that groundwater from their wells was not suitable for drinking. In addition, the training also emphasized that not all groundwater colorless, tasteless and odorless suitable for consumption purposes. This can be done (consumption) if the groundwater is taken from volcanic mountain springs (volcanoes) because based on previous research, water from volcanic springs is less polluted or still within the safe range of drinking.

\section{Discussion}

We have summarized the right steps in implementing this method. Generally, the steps have been discussed in methods but we will explain in detail. The steps in the door to door method including community respond as follow: We,came to the house of the community by first greeting or knocking on the door. In this step, the community would to ask about the purpose of our coming. So, keep friendly. Next, we introduced himself which includes the name, occupation, institution, and purpose to house. Then, the We asked all matters related to the topic of the material. This was done so that the presenter could determine what training material should be given. In this step, the presenter asked about the quality of water especially the characteristics of good water for drinking. Generally, they known the characteristics but not for micro scale. The community's knowledge did not meet the presenter' expectations so the presenter provided the correct material about the community's ignorance. The media used was in the form of paper containing the results of research. It would be nice if the media can be given free of charge to the public so that people can relearn. The presenter gave the opportunity for the public to ask questions. There were no question limits. In this step, we had to patient to explain. Next, question and answer session were complete, the presenter moved to the next participant, ending with thanks. From these steps, there is the most important thing that influences the success of this method, namely active

7 Siringoringo, Rizki, and Nababan, “Engineering , Environment, and Technology Hydrogeochemical and Groundwater Assessment for Drinking Purpose at ITERA Campus Area and Its Surroundings." 
motivation. If we are actively motivated, the community will also be actively motivated ${ }^{8}$. This is what we did, which is to train the community of high active motivation. In ending this program, we motivated the community to see the water correctly. They had to analysis in physical or molecular. We advised them to not drink water based on just physical analysis only except from branded water such as Aqua, Minerale, etc. We also encourage them to spread the knowledge to their family and other people.

Based on observations in the field, the response of community was very enthusiastic, it could be seen by the absence of rejection from the community when the presenter (author) and assistant came (figure 4). In addition, the public diligently asked the presenter if there is something that did not yet understand.

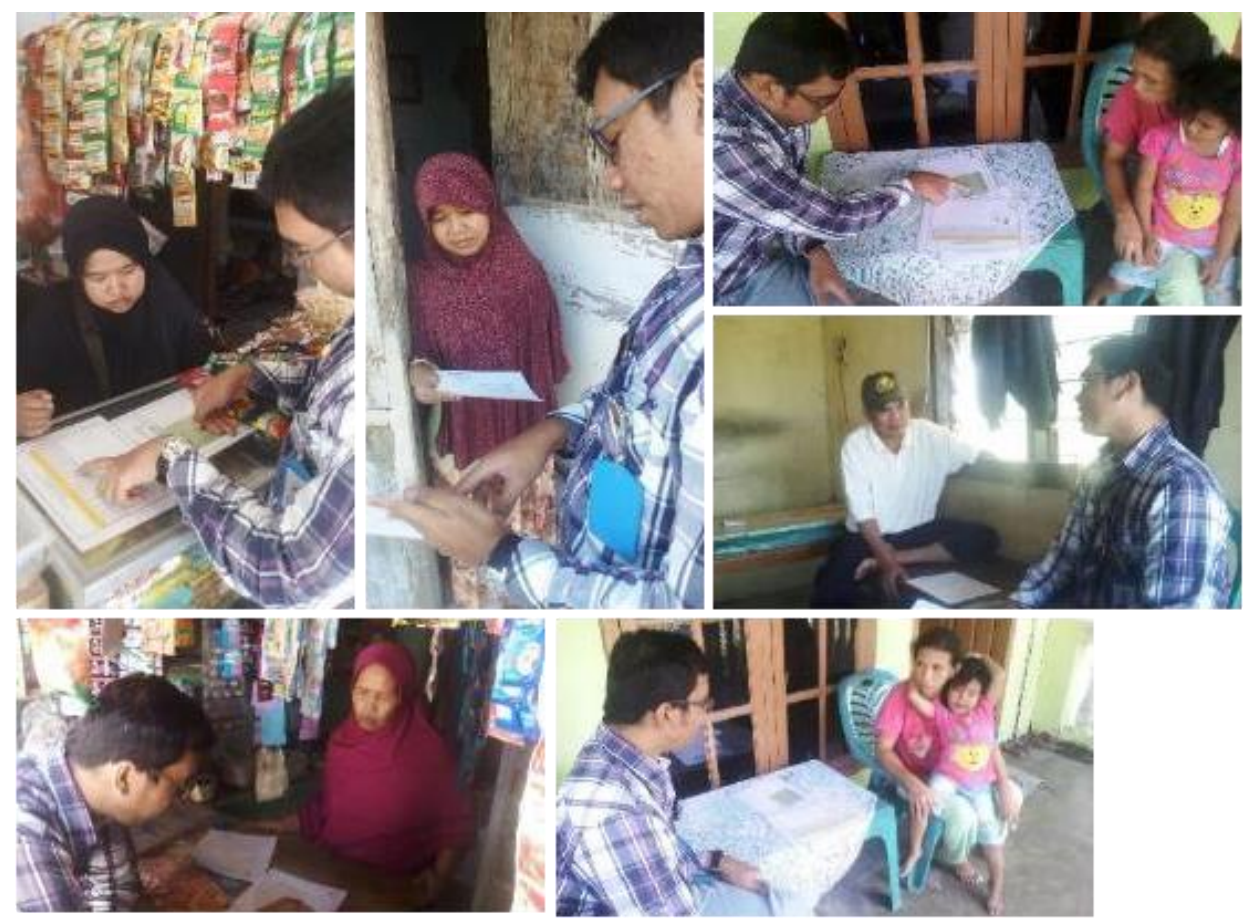

Figure 4. Groundwater identification training activities

8 Raden Agus Budiharto and Abdul Wahab Syahroni, "Pendampingan Pemanfaatan Duolingo Melalui Smartphone Sebagai Alat Pengajaran Dan Pembelajaran Bahasa Inggris Bagi Masyarakat," CARADDE: Jurnal Pengabdian Kepada Masyarakat 2, no. 2 (2020): 339-346. 


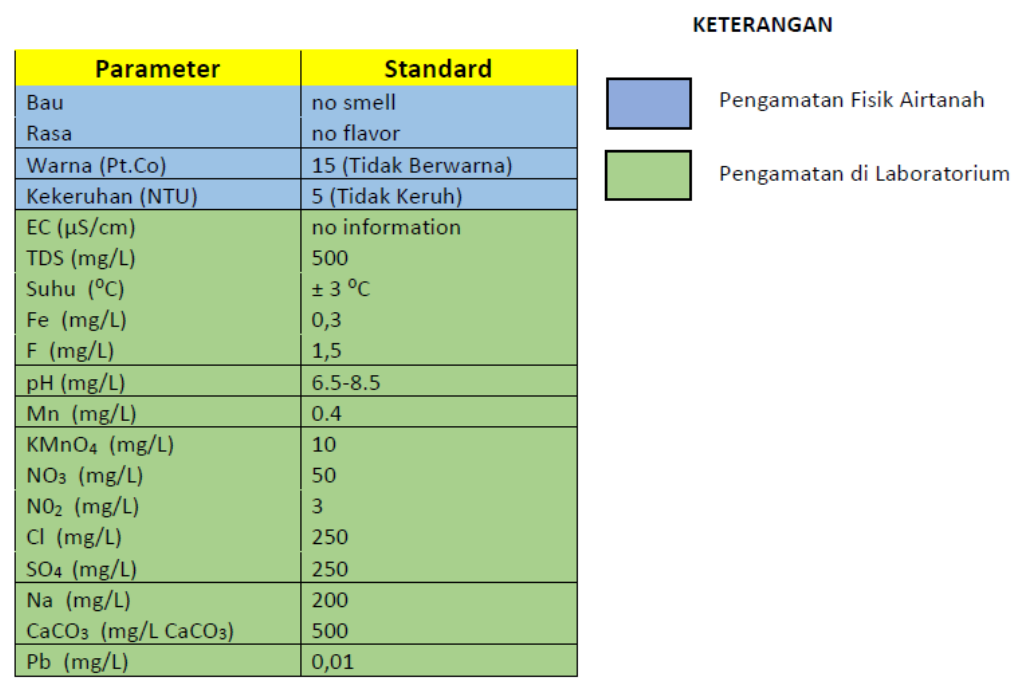

Figure 5. Drinking water standards refer to PERMENKES NO. 492 / MENKES / PER / IV / 2010

HASIL ANALISIS LABORATORIUM CONTO AIRTANAH MENGACU PADA

PERMENKES N0.492/MENKES/PER/IV/2010

\begin{tabular}{|c|c|c|c|c|c|c|c|c|c|c|c|c|c|c|c|c|c|c|c|}
\hline $\begin{array}{l}\text { Kode } \\
\text { Sampel }\end{array}$ & Bau & Rasa & $\begin{array}{l}\text { Warna } \\
(\mathrm{Pt}, \mathrm{Co})\end{array}$ & $\begin{array}{l}\text { Kekeruhan } \\
\text { (NTU) }\end{array}$ & $\begin{array}{c}E C \\
(\mu \mathrm{s} / \mathrm{cm})\end{array}$ & $\begin{array}{c}\text { TDS } \\
(\mathrm{mg} / \mathrm{L})\end{array}$ & $\begin{array}{l}\text { Suhu } \\
\left({ }^{\circ} \mathrm{C}\right)\end{array}$ & $\begin{array}{c}\mathrm{Fe} \\
(\mathrm{mg} / \mathrm{L})\end{array}$ & $\mathrm{F}(\mathrm{mg} / \mathrm{L})$ & $\mathrm{pH}$ & $\begin{array}{c}\mathrm{Mn} \\
(\mathrm{mg} / \mathrm{L})\end{array}$ & $\begin{array}{l}\mathrm{KMnO4} \\
(\mathrm{mg} / \mathrm{L})\end{array}$ & $\begin{array}{c}\mathrm{NO}_{3} \\
(\mathrm{mg} / \mathrm{L})\end{array}$ & $\begin{array}{c}\mathrm{N} 0_{2} \\
(\mathrm{mg} / \mathrm{L})\end{array}$ & $\underset{(\mathrm{mg} / \mathrm{L})}{\mathrm{Cl}}$ & $\begin{array}{c}\mathrm{SO4} \\
(\mathrm{mg} / \mathrm{L})\end{array}$ & $\begin{array}{c}\mathrm{Na} \\
(\mathrm{mg} / \mathrm{L})\end{array}$ & $\begin{array}{l}\mathrm{CaCO} 3 \\
(\mathrm{mg} / \mathrm{L} \\
\mathrm{CaCO})\end{array}$ & $\begin{array}{c}\mathrm{Pb} \\
(\mathrm{mg} / \mathrm{L})\end{array}$ \\
\hline A1 & TB & $T R$ & 5 & 2,41 & 433 & 259 & 25,7 & 0,01 & 0.543 & 5.86 & 0,2 & 6,81 & 45,2 & 0,3 & 57.7 & 15.9 & 43.5 & 50.5 & 0,001 \\
\hline A2 & TB & $T R$ & 5 & 0.07 & 365 & 219 & 25.8 & 0.01 & 0.063 & 5.3 & 0.458 & 4.36 & \begin{tabular}{|l|} 
\\
\end{tabular} & 0.006 & 58.6 & 2.76 & \begin{tabular}{|l|}
47.1 \\
\end{tabular} & 42 & 0.001 \\
\hline A3 & TB & $T R$ & 5 & 1.51 & 752 & 526 & 25.7 & 0.045 & 0.273 & 7.1 & 0.2 & 6.81 & 55.7 & 0.004 & 70.6 & 48 & 78 & 110 & 0.001 \\
\hline A4 & B & $\mathrm{R}$ & 10 & 29.7 & 248 & 149 & 25.7 & 1.04 & 0.123 & 6.43 & 0.2 & 10.5 & \begin{tabular}{|l|l|} 
\\
\end{tabular} & 0.004 & 22.9 & 17.8 & \begin{tabular}{|l|}
24.9 \\
\end{tabular} & 59 & 0.001 \\
\hline A5 & TB & TR & 5 & 4.94 & 778 & 545 & 25.7 & 0.01 & 0.255 & 5.54 & 1.11 & 21.8 & 114 & 0.665 & 133 & 35.7 & \begin{tabular}{|l}
77.4 \\
\end{tabular} & 126 & 0.001 \\
\hline A7 & TB & TR & 5 & 15.7 & 535 & 375 & 25.7 & 0.232 & 0.255 & 6.5 & 0.2 & 10.8 & \begin{tabular}{|l}
22.7 \\
\end{tabular} & 0.117 & 53.9 & 38.8 & \begin{tabular}{|l|l}
41.9 \\
\end{tabular} & 118 & 0.001 \\
\hline A8 & B & $R$ & 20 & 65.4 & 138 & 83 & 24.8 & 0.581 & 0.233 & 6.64 & 0.2 & 4.15 & \begin{tabular}{|l} 
\\
\end{tabular} & 0.004 & 16.6 & 21.5 & \begin{tabular}{|l}
13.9 \\
\end{tabular} & 19 & 0.001 \\
\hline A9 & TB & TR & 5 & 7.66 & 326 & 228 & 25.7 & 0.01 & 0.181 & 6.58 & 0.2 & 11.3 & 25.9 & 0.073 & 27.8 & 30.3 & 38.9 & 61 & 0.001 \\
\hline
\end{tabular}

Figure 6. Laboratory analysis results. The writing in red indicates that the content / compound exceeds the allowable threshold

The implementation of this service was carried out on the basis of the economic aspects of the region that are growing in the future and concerns that people's knowledge of good water quality is still lacking. Therefore we did community devotion by door to door method or lecture method. We chose this method so the public can be more free to discuss with us. In addition, devotion was also done on the basis of the poor quality of water in their homes. We found that the knowledge of good water especially for drinking water needs is still lacking which is comparable to their low educational background. 
So we asked them what they knew about the good things of water. we found that they only know based on physical properties only. Whereas good water quality must also contain metal content and living things are very minimal. The community was given two examples of water, namely good and poor water. Both look clear but chemically and biologically have a very contrast value. Then we describe in detail the chemical and biological content in each water. After that, a free question and answer session was opened for them to understand. Once they understand, they were encouraged to spread this knowledge to their families and others so as to implicate the behavior of the community ${ }^{9}$. With this kind of encouragement, it is expected that in the future people will be more independent or wise in using water, especially for drinking water purposes because they trust each other ${ }^{10}$. With the condition of covid 19 as it is today, changes in public behavior will have an impact on improving public health so can to contribute to the strength of each individual community's body in the face of pandemic covid-19 and other diseases ${ }^{11}$.

\section{Conclusion}

Community training using the door to door method is a very good method, especially during the COVID 19 pandemic as it is today. With its advantages such as cheap, effective, and minimal permissions. The material given to the community was the result of previous research so that the community can be helped directly. The response of the community was very good. It can be seen from the many questions asked. They felt their knowledge has improved. Hopefully, they can implement the knowledge and share to other people. In addition, the use of a small whiteboard as a delivery medium will be much better so that people become more understanding.

\section{Acknowledgements}

Highest appreciation to Head of Way Huwi Villages and his community for their support and hospitality so we could do this devotion fluently. We also expressed high appreciation to ITERA for permission and administration support during the devotion.

${ }^{9}$ Rachmini Saparita et al., "Sustainable Community Development for Developing of Coastal Areas in Alor Regency, East Nusa Tenggara, Indonesia," Jurnal Pemberdayaan Masyarakat: Media Pemikiran dan Dakwah Pembangunan 4, no. 2 (2020): 323-344.

${ }^{10}$ Islah Islami and Moh. Abu Suhud, "Pemberdayaan Masyarakat Berbasis Pondok Pesantren: Studi Kasus Di Pesantren Joglo Alit," Jurnal Pemberdayaan Masyarakat: Media Pemikiran dan Dakwah Pembangunan 4, no. 1 (2020): 1-22.

${ }^{11}$ Mukti Hamjah Harahap et al., "UPAYA PENINGKATAN POLA HIDUP BERSIH SEHAT DI DESA IBUS MELALUI DISEMINASI TEKNOLOGI TEPAT GUNA FILTER AIR, CUCI TANGAN DIGITAL DAN MESIN PEMBUAT SABUN UNTUK MENGHADAPI PANDEMI COVID-19," Journal Pengabdian Kepada Masyarakat 26, no. 4 (2020): 233-237. 


\section{References}

Agustina, Dian. "Pendampingan Mitigasi Bencana Gempa Bumi Dan Tsunami Berbasis Pengetahuan Lokal Pada Masyarakat Rentan Bencana Di Kabupaten Mukomuko Bengkulu." Engagement: Jurnal Pengabdian Kepada Masyarakat 1, no. 3 (2020): 8799.

Budiharto, Raden Agus, and Abdul Wahab Syahroni. "Pendampingan Pemanfaatan Duolingo Melalui Smartphone Sebagai Alat Pengajaran Dan Pembelajaran Bahasa Inggris Bagi Masyarakat." CARADDE: Jurnal Pengabdian Kepada Masyarakat 2, no. 2 (2020): 339-346.

Dandirwalu, Resa, Desviana Maspaitella, Nining Gan, Yonaria Pattiapon, Vonda Leasa, Pingkan P. Alfons, Jems Porumau, et al. "Pendampingan Perilaku Hidup Bersih Dan Sehat Berbasis Gereja Di Sekolah Minggu Jemaat Gereja Protestan Maluku (GPM) Tihulale Kabupaten Seram Bagian Barat." Engagement: Jurnal Pengabdian Kepada Masyarakat 4, no. 1 (2020): 225-236.

Harahap, Mukti Hamjah, Hesti Fibriasari, Miftahul Ihsan, Irfandi, Deo Demonta Panggabean, and Dedy Husrizal Syah. "UPAYA PENINGKATAN POLA HIDUP BERSIH SEHAT DI DESA IBUS MELALUI DISEMINASI TEKNOLOGI TEPAT GUNA FILTER AIR, CUCI TANGAN DIGITAL DAN MESIN PEMBUAT SABUN UNTUK MENGHADAPI PANDEMI COVID-19." Journal Pengabdian Kepada Masyarakat 26, no. 4 (2020): 233-237.

Islami, Islah, and Moh. Abu Suhud. "Pemberdayaan Masyarakat Berbasis Pondok Pesantren: Studi Kasus Di Pesantren Joglo Alit." Jurnal Pemberdayaan Masyarakat: Media Pemikiran dan Dakwah Pembangunan 4, no. 1 (2020): 1-22.

JP, Dheni Saputra, Ofik Taufik Purwadi, and Sumiharni. "Studi Air Tanah Berbasis Geographics Information System (GIS) Di Kota Bandar Lampung." Rekayasa Sipil dan Desain 4, no. 3 (2016): 469-480.

Kabupaten Lampung Selatan, Badan Pusat Statistik. STATISTIK KESEJAHTERAAN RAKYAT KABUPATEN LAMPUNG SELATAN 2020, 2020.

Saparita, Rachmini, Diki Nanang Surachman Hendarwin M. Astro, Sukirno, Eki Karsani, and Apriliyadi. "Sustainable Community Development for Developing of Coastal Areas in Alor Regency, East Nusa Tenggara, Indonesia." Jurnal Pemberdayaan Masyarakat: Media Pemikiran dan Dakwah Pembangunan 4, no. 2 (2020): 323-344.

Siringoringo, Luhut Pardamean, Reza Rizki, and Janner Nababan. "Engineering , Environment, and Technology Hydrogeochemical and Groundwater Assessment for Drinking Purpose at ITERA Campus Area and Its Surroundings." Journal of Geoscience, Engineering, Environment, and Technology 04, no. 01 (2019): 40-48. 
Jurnal Pengabdian kepada Masyarakat Volume 05, Number 01, May 2021, pp. 046 - 058

Yudhoyono, Susilo Bambang. Daftar Cekungan Airtanah Di Indonesia, 2011. 